\title{
Bluebirds and Her Majesty's Mail
}

by Mrs. L. Harrison, Ohaton, Alta.

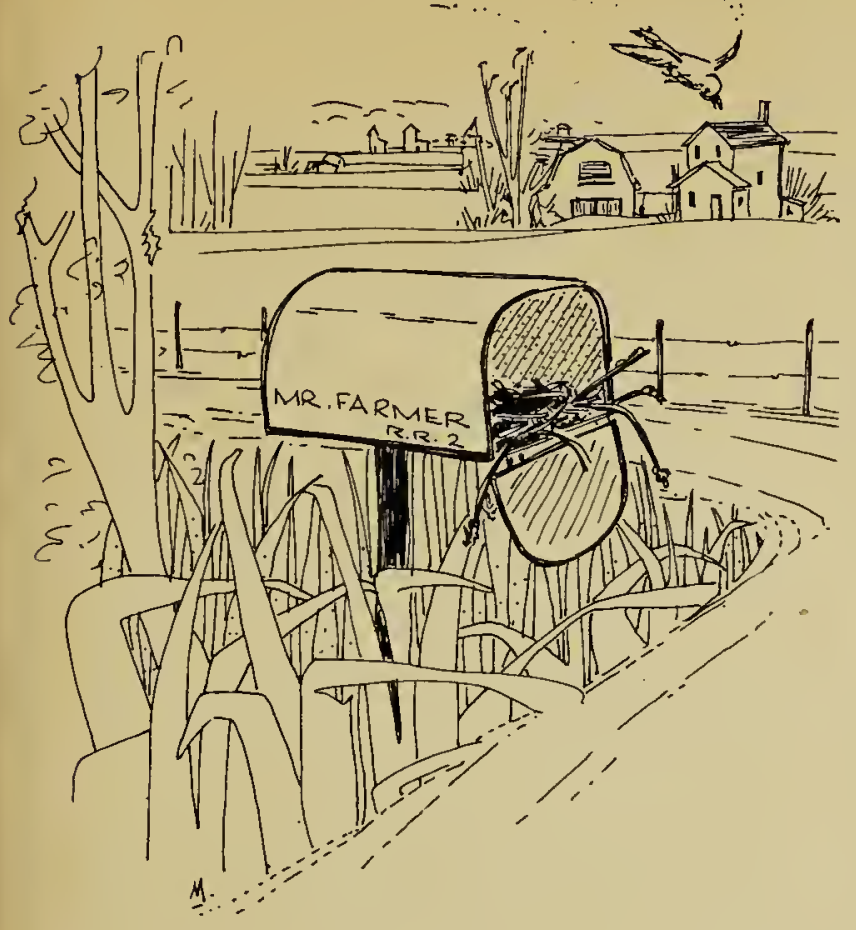

Every writer is supposed to have a robin story tucked away somewhere to tell in the spring of the year, like the one about the man who never did get his house painted. Every spring he got out his paint pots and ladder, climbed up, discovered a robin rearing her young in the eaves, climbed down again, and went fishing. His house remained the community disgrace year after year.

It wasn't the robins that upset our schedule. It was a pair of Mountain Bluebirds that interfered with Her Majesty's mail here last summer.

One day I went down to the mail box to leave some letters for the mail man who was due later in the day. There was a pile of dried grasses in the further end, with a little hollow for the bird to lay her eggs in. It looked exactly like the nest of a House Sparrow. Just as I reached in to tear the nest out, something stayed my hand. A male blu ebird had been a daily visitor at our bird bath for the last few days. I didn't see his mate and concluded that she had met with an accident. It just could be, though, that she was busy establishing a home somewhere. I watched. Soon a pair of bluebirds flew down to the top of the mail box and entered through the letter slot, from which the flap had long disappeared.
I phoned our postmaster. "What do the postal authorities at Ottawa say about birds building in mail boxes?" I asked him. He laughed. He was also our mail carrier. He said, "Every third mail box on the route has a pair of sparrows in it."

"Ours are bluebirds," I told him.

He hesitated, impressed. "With your permission I can leave your mail in a substitute box until the young are reared," he said.

And so it came to pass. My husband built a tight box with a lid and we set it up beside the one housing the bluebirds.

All went well. Five little pale blue eggis soon graced the nest. Four little fledglings emerged and were duly raised. Daily the parents came to our front yard for their bath. I never heard them sing. Mountain Bluebirds are silent birds. Occasionally when in flight with more of their kind, they will break their silence with a low sweet call.

I saw our postmaster in the fall. He asked me about our bluebirds. "I hardly dared breathe when I left your mail for you last summer," he said.

But actually our bluebirds were quite tame. We often looked in upon them, and although the mother bird watched us with anxious eyes, she did not take flight.

We were not fortunate enough to see the young leave their nest and learn to fly. One day when I went down to the corner with some letters, I found them all feathered and swarming all over the interior of the box. Later that same week they were gone. The nest was empty, except for bits of pale blue shells and the one egg which had not hatched. I brcught that up to my little daughter who would like to collect eggs, if her heart would let her.

It is reported that bluebirds will always return to the spot where they have had a successful hatch. With this in mind, we have carefully put away our substitute mail box, hoping for just such another emergency next summer. 